\title{
Biochar impact on herbicides behavior in the soils: an approach in Brazil
}

\author{
Impacto do biochar no comportamento de herbicidas em solos: \\ um enfoque no Brasil
}

\section{Kassio Ferreira Mendes ${ }^{1 *}$, Cassio de Souza Almeida ${ }^{1}$, Miriam Hiroko Inoue ${ }^{2}$, Tatiane Beatriz Mertens ${ }^{3}$, Valdemar Luiz Tornisielo ${ }^{1}$}

\begin{abstract}
The application of biochar to soils because of beneficial effects is proven by many international researchers and this can increase herbicides sorption and reduce effectiveness on weed management. Positive impacts are reported in relation to the environmental behavior of herbicides, since the increase of the sorption reduces the leaching of these products to groundwater. Negative impacts are reported in relation to agronomic management of herbicides, since the sorption increase reduces the availability of these products in the soil, reducing the residual effect for weed control. In Brazil, biochar is produced by several private companies and pyrolysis units, but the cost for production is still very high, probably due to lack of government incentive, low use of producers, and awareness of the benefits. Although biochar has been used for several decades in other countries, in Brazil there are still few studies developed by soil researchers, and biochar efficiency on the bioavailability of herbicide in the soil is still unknown by many weed science Brazilian researchers. Against the above, the objective of this review was to evaluate the bioavailability of herbicides in biochar-amended soils and highlight the research with biochar in Brazilian conditions, besides presenting the benefits to soil with biochar addition. Little is known about the herbicides behavior in Brazilian soils amended with biochar, which can be used with greater intensity in modern agriculture. So more research is needed under our conditions to really we understand the dynamics of this product in the soil.
\end{abstract}

Keywords: black carbon, retention, management practices, soil behavior

Resumo - A aplicação de biochar (biocarvão) em solos por causa dos efeitos benéficos é comprovada por muitos pesquisadores internacionais e isto pode aumentar a sorção dos herbicidas e reduzir a eficácia destes no manejo das plantas daninhas. Impactos positivos são relatados em relação ao comportamento ambiental dos herbicidas, pois o aumento da sorção reduz a lixiviação destes produtos para as águas subterrâneas. Impactos negativos são relatados em relação ao manejo agronômico dos herbicidas, pois o aumento da sorção reduz a disponibilidade destes produtos no solo, diminuindo o efeito residual para o controle das plantas daninhas. No Brasil, o biochar é produzido por várias empresas privadas e unidades de pirólise, entretanto, o custo para produção ainda é muito alto,

Received: September 06, 2017. Accepted: April 17, 2018.

${ }^{1}$ Laboratório de Ecotoxicologia, Centro de Energia Nuclear na Agricultura, Universidade de São Paulo - USP, Av. Centenário, 303, São Dimas, CEP 13416-000, Piracicaba, SP, Brasil. E-mail: kassio_mendes_06@hotmail.com; cassio.almeiida@hotmail.com; vltornis@cena.usp.br

${ }^{2}$ Departamento de Agronomia, Universidade do Estado de Mato Grosso - UNEMAT, Tangará da Serra, MT, Brasil. E-mail: miriamhinoue@hotmail.com

${ }_{3}^{3}$ Departamento de Agronomia, Universidade Estadual Norte do Paraná - UENP, Bandeirantes, PR, Brasil.

E-mail: tati_mertens@hotmail.com 
provavelmente por falta de incentivo do governo, baixo uso dos produtores e consciência dos benefícios. Embora o biochar seja utilizado há várias décadas em outros países, no Brasil ainda há poucos estudos desenvolvidos por pesquisadores na área de solos, e a eficiência do biochar na biodisponibilidade de herbicidas no solo ainda é desconhecida por muitos pesquisadores brasileiros na área de plantas daninhas. Diante do exposto, o objetivo desta revisão foi avaliar a biodisponibilidade de herbicidas em solos modificados com biochar e destacar a pesquisa com biochar em condições brasileiras, além de apresentar os benefícios ao solo com a adição do biochar. Pouco se sabe sobre o comportamento de herbicidas em solos brasileiros modificados com biochar, que pode ser utilizado com maior intensidade na agricultura moderna. Então, mais pesquisas são necessárias sob nossas condições para realmente entender a dinâmica deste produto no solo.

Palavras-chave: carbono preto, retenção, práticas de manejo, comportamento no solo

\section{Introduction}

Biochar is produced through the by-product of a thermal process conducted under low oxygen or oxygen-free conditions (pyrolysis) to convert any vegetative biomass to biofuel, according to Clay and Malo (2012). Pyrolysis is a process that involves the application of heat to biomass in order to concentrate the heat and collect the by-products (Khorram et al., 2016). It is an interesting alternative, mainly for the treatment of biomass residues in general, aiming at its direct application of soil or composing the compost. The main difference between pyrolysis and incineration is that by pyrolysis it is possible to recover condensable gases (pyroligneous or bio-oil) and those that do not condense, but with high combustion power providing additional energy for the processing unit. Although, chars and charcoal-like materials occur naturally in soils and are considered part of the soil organic carbon (SOC) pools (Skjemstad et al., 1996). High fertility associated with anthropogenic soils (e.g. Terra Preta de Índio) in the Amazon has been related to the high SOC content in the form of char and the practice of 'slash and char' by the pre-Columbian indigenous people of the Amazon (Glaser et al., 2001).

Thus, in addition to the natural biochar found in nature, biochar can be artificially produced, and there are a wide variety of end-products that can be manufactured depending on processing parameters and initial raw feedstocks, living or dead vegetables
(Bridgewater, 2003). It is important to note that the parameters of the pyrolytic process, such as temperature, heating rate, and pressure, can change the recovery amounts of each end-product, energy values of the bio-oils and the physicochemical properties of the biochar (Yaman, 2004).

Biochar has emerged as a viable option for sequestering carbon (C) in soil (Lehmann et al., 2006). However, agronomic responses to biochar application are likely to be influenced by several aspects of chemical composition of the biochar: the total and available plant nutrients, the liming equivalence, the presence of toxic constituents, and the surface properties of biochar (Singh et al., 2010). Depending on the type and amount of biochar applied, the changes in soil properties associated with the application (e.g. soil pH, electrical conductivity) as well as the physicochemical properties of the char itself, may impact the use, rates, efficacious properties, and fates of pesticide used in agronomic management, such as herbicides (Clay and Malo, 2012).

The great concern of researchers is that addition of biochar in the soil can potentiate sorption processes, and it may have negative impacts on weed management, reducing herbicide efficacy, consequently it will be necessary to apply higher doses of herbicides (Clay and Malo, 2012). On the other hand, positive impacts are also reported with the addition of biochar in soil, such as the increased sorption capacity of herbicides, due to 
carbonaceous sorbents of biochar, providing reduced leaching of these products into the groundwater. Other positive points that increased sorption may be beneficial in terms of reducing herbicide residues in rotation or succession crops, thus it can eliminate the carryover effect (Beesley et al., 2011). In view of this situation, there is a growing demand on studying biochar under tropical conditions, such as in Brazil, which has one of the largest areas of the Amazon with natural biochar and already has private companies that produce biochar through the pyrolysis of different feedstocks.

According to data from International Biochar Initiative (IBI, 2017) in South America there are not regional biochar groups that help support local biochar research and projects applicable to that geographical area. Although biochar has been used for several decades in other countries, in Brazil there are still few studies developed by soil researchers, and the influence of biochar on the bioavailability of herbicides in the soil is still unknown by many weed scientist Brazilian. Given the above, the objective of this review was to evaluate the bioavailability of herbicides in biochar-amended soils and highlight the research with biochar in Brazilian conditions, besides presenting the benefits to soil with biochar addition.

\section{Envrironment and soil agricultural benefits of biochar}

The interest in the effects of biochar application on plant growth, soil properties, and environmental contaminants has spurred a significant amount of research in recent years (Ippolito et al., 2012). Biochar is posing many benefits to the environment, agriculture and economy in the longer run, so it is highly recommended to incorporate it in agriculture practices (Rehman and Razzaq, 2017). Spokas et al. (2012) reported that although current economics may not be favorable for large-scale production agriculture utilization of biochar, the potential exists for biochar to provide environmental quality benefi ts and to improve nonproductive or degraded soils. On the other hand, intensive study of biochar-rich dark earths in the Amazon (Terra Preta de Índio) has led to a wider appreciation of biochar's unique properties as a soil enhancer (IBI, 2017).

Biochar can be an important tool to increase food security and cropland diversity in areas with severely depleted soils, scarce organic resources, and inadequate water and chemical fertilizer supplies. Biochar also improves water quality and quantity by increasing soil retention of nutrients and pesticides for plant and crop utilization, which these products can be unavailable to crop and weed. More nutrients stay in the soil instead of leaching into groundwater and causing pollution (IBI, 2017). As a soil corrector, biochar creates a recalcitrant $\mathrm{C}$ reserve with a negative charge, serving as a network that removes $\mathrm{CO}_{2}$ from the atmosphere. The large range of these atmospheric and soil benefits caused by the addition of biochar are illustrated in Figure 1.

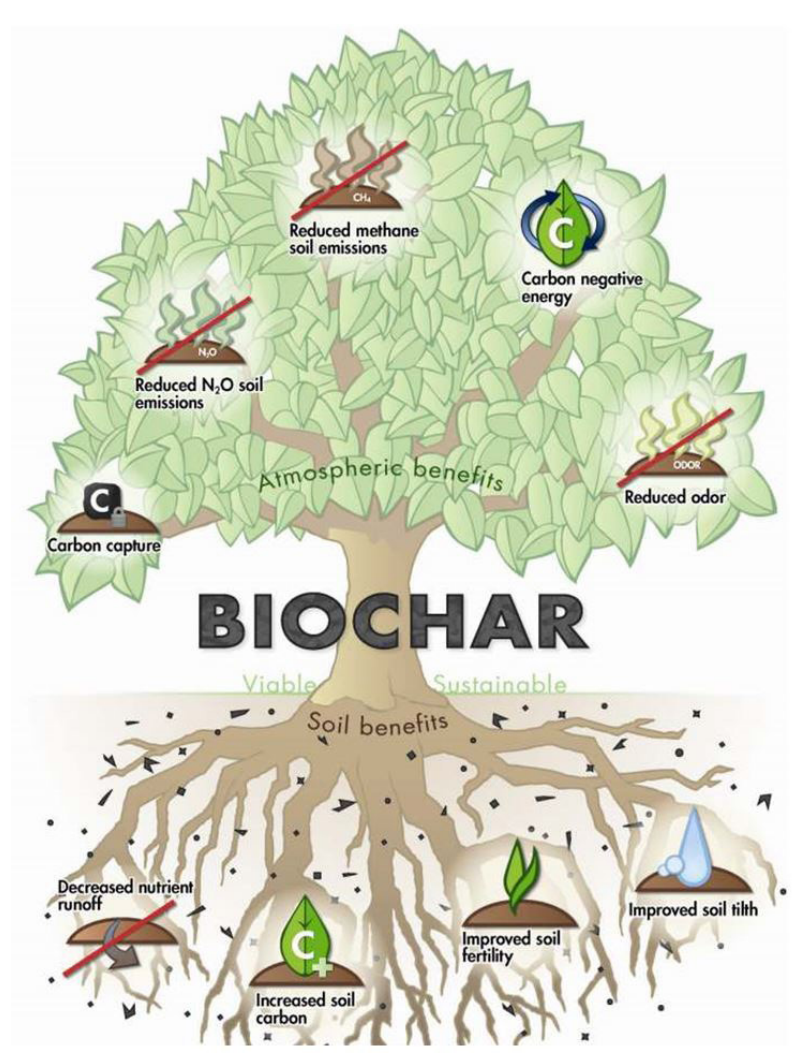

Figure 1. Atmospheric and soil benefits of biochar. Source: IBI (2017). 
In agriculture, biochar has several effects, as reported above, as interference in the bioavailability of nutrients to the crop, which the increase in nutrient retention capacity reduces the total fertilizer need. Singh et al. (2010) reported that feedstock source and/or pyrolysis temperature significantly influence charge properties and the contents of $\mathrm{C}$, nutrients, and liming potential of biochars. It is thus important to characterise biochars in relation to their properties, thereby allowing users to select the most suitable biochar for a specific soil application; for example, nutrient-rich and high cation exchange capacity (CEC) biochars could potentially be applied to degraded, nutrient poor soils, or biochars with high acid-neutralising capacity could be applied to alleviate soil acidity. However, further research on the forms and bioavailability of nutrients present in biochar is required.

CEC of the biochar is affected by the type of feedstock used and by the pyrolysis temperature. High temperatures cause CEC to be low due to loss of functional groups. With the maturation of the biochar its CEC increases due to the formation of functional groups such as carboxyl and other oxygenates on its surface. At the same time, aging causes a substantial reduction of the anion exchange capacity (AEC) derived from the disappearance of the positive charge from the surface.

It is necessary to take into account the use of biomass, as it has other uses in the ecosystem, and combine them with human needs. It is important to consider possible conflicts between energy production and biochar versus food production. However, the use of waste as soil covers, to protect its surface, in balance with the use of biochar. While biochar will improve soil quality and productivity, cover crop may be useful to control water and wind erosion. As a consequence, not all biomass should be used for biochar production.

All these issues and others deserve special attention and more studies, especially in tropical regions, such as in Brazil.

\section{Agricultural use of biochar in Brazil}

In Brazil, field experimentation with use of biochar started about 15 years ago and the first studies were focused on Amazonian lands. Maia et al. (2011) reported that biochar technology is being studied by Embrapa and their partners together with other low carbon practices such as no-tillage cropping systems, integrated crop-livestock-florestry systems, forestation and degraded land restoration. To produce biochar from native florest destruction is nonsense in any environmental analysis. Besides, sustainability is a concept that is increasingly present in industrial management, with recent initiatives taking place in the private forestry sector (Maia et al., 2011).

Carvalho et al. (2013) reported that wood biochar application provided an increase in soil $\mathrm{pH}, \mathrm{K}, \mathrm{Ca}, \mathrm{Mg}, \mathrm{CEC}, \mathrm{Mn}$ and nitrate while decreasing $\mathrm{Al}$ content and potential acidity of aerobic rice growth and grain yield in a clayey Rhodic Ferralsol in the Brazilian Savannah. Effects of biochar on soil properties may change with time, leading to responses quite different from those observed in this study.

In other studies Eykelbosh et al. (2015) found that biochar (charcoal produced from pyrolyzed filtercake) attenuated dissolved organic carbon leaching, likely through stabilization of complex compounds already present in a Brazilian sugarcane soil, but did not lessen $\mathrm{NO}^{3-}$ fluxes. Thus, biochar amendments in vinasse application areas may decrease carbon leaching.

Petter and Madari (2012) described that the technology of using biochar as soil conditioner also in the Brazilian Savannah is a promising future alternative to improve soil properties and the production of crops such as soybeans and aerobic rice in a sustainable manner. Biochar use in order to improve soil properties has been studied (Maia et al., 2011), but its real potential as reducing the herbicide bioavailability is still little understood, mainly in Brazil. 


\section{Biochar use and herbicides behavior in soils}

Several studies have demonstrated that biochar amendment can lead to higher irreversible sorption of herbicides (Yang et al., 2006; Yu et al., 2006; Cabrera et al., 2011, 2014; Eibisch et al., 2015; Mendes et al., 2017). The irreversible sorption process of herbicide on biochar included surface-specific sorption, entrapment into micropores, and partitioning into condensed with cabonaceus material (Khorram et al., 2016). Sorption to biochar may ultimately increase herbicide persistence in the environment because they will be protected from microbial degradation (Beesley et al., 2011). A summary of selected recently reported studies developed in the world using biochars and their influences on can be found in Table 1 .

According to Petter and Madari (2012), as there is partial oxidation of the edges of the aromatic structures of the biochar, there is an increase in the exposure of charges. These characteristics may increase interaction with ionizable or non-ionizable molecules, since the physicochemical composition of organic matter soil is highly variable. The contribution of biochar is given by the increase of total organic carbon, humic acid and humina (Petter et al., 2016).

This presents a challenge to manage organic contaminants, such as herbicides; sorption can reduce short-term environmental risk but may not always ultimately be remedially beneficial (Beesley et al., 2011). This depends on the sorption strength and factors inherent to the contaminant, char and soil which can influence retention over time.

The lack of information on biochar use and impact in Brazil requires more research in this area, on the other handthere are several biochar regional groups worldwide and these groups often hold conferences and meetings, provide updates on regional biochar projects to their members, undertake projects such as field tests and biochar production, advocate for policy on the local and regional levels, write and publish reports, and provide a network of people all working in a similar geographic area (IBI, 2017).

Based on the scientific reports cited in the previous sections, a schematic diagramof the effects of biochar amendment on the environmental behavior of herbicides in soil is shown in Figure 2, according to Khorram et al. (2016). The same

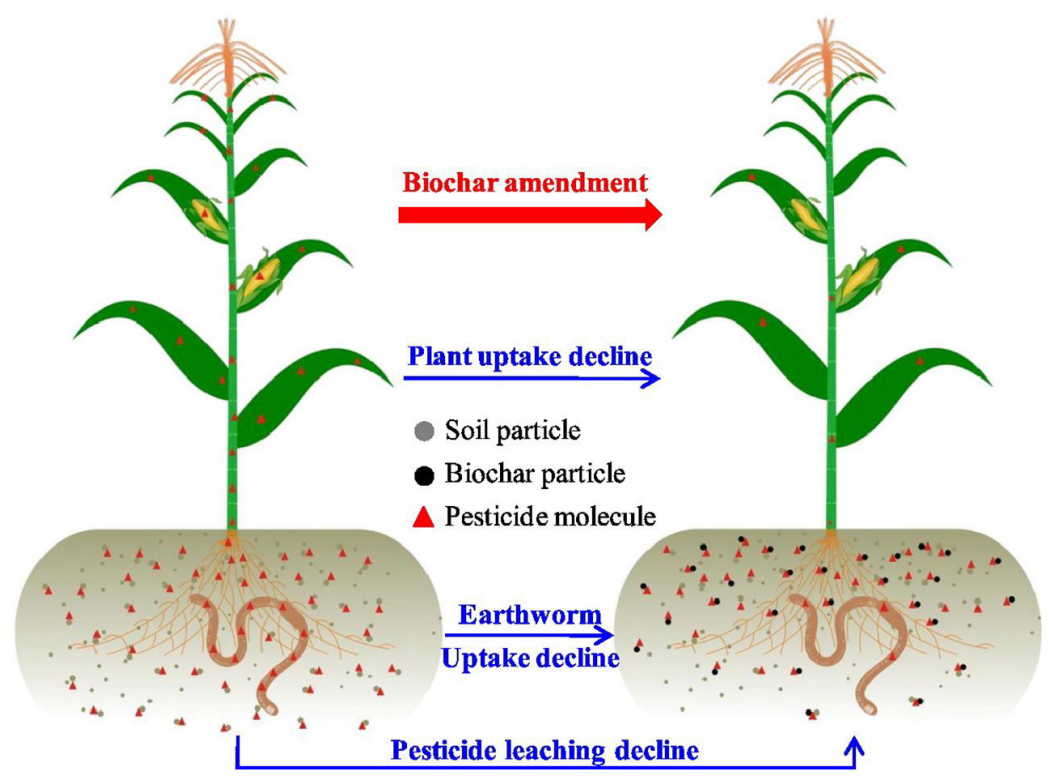

Figure 2. A schematic diagram of biochar amendment effects on the environmental behavior of pesticides (e.g. herbicides) in soil. Source: Khorram et al. (2016). 


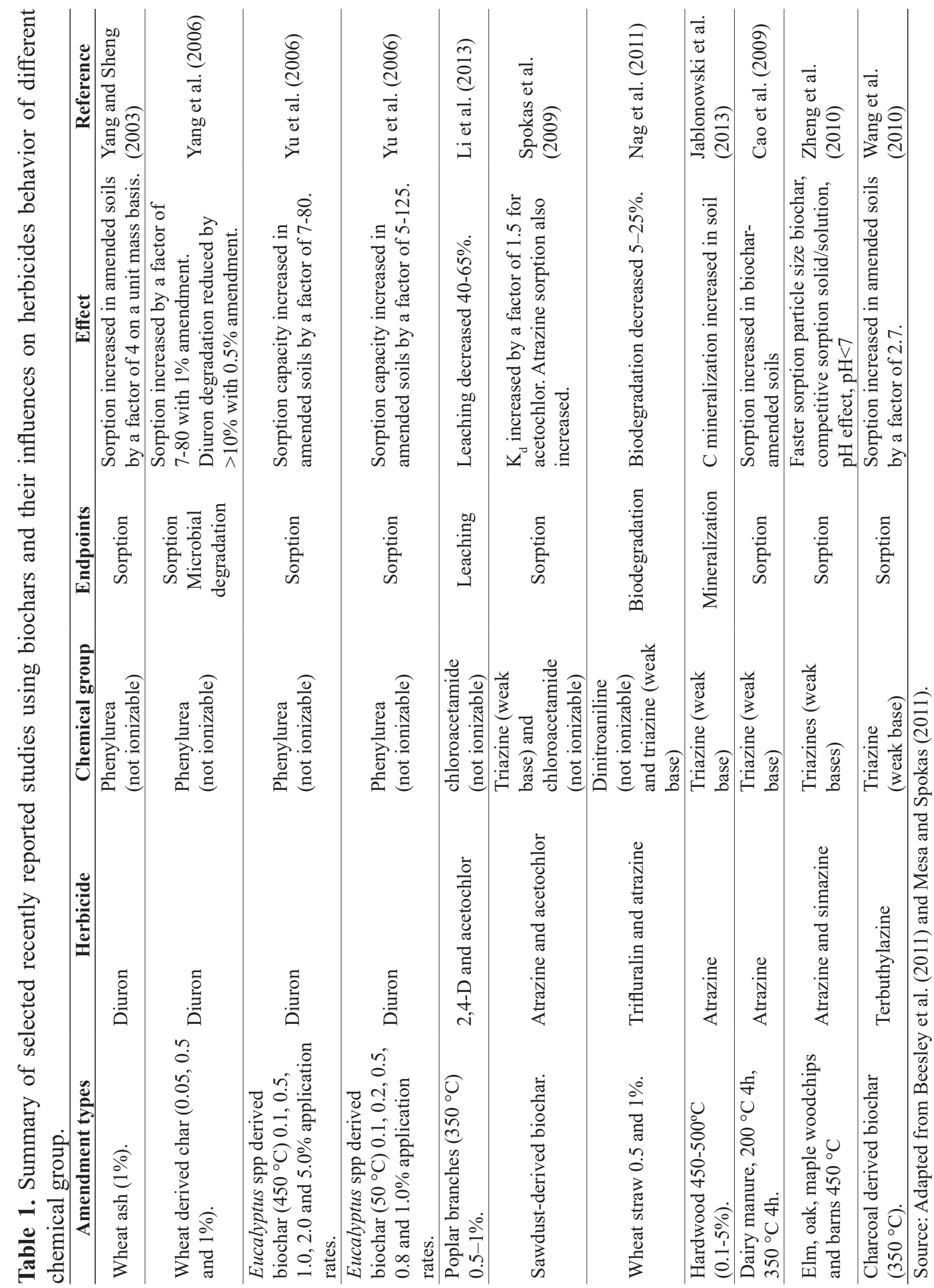




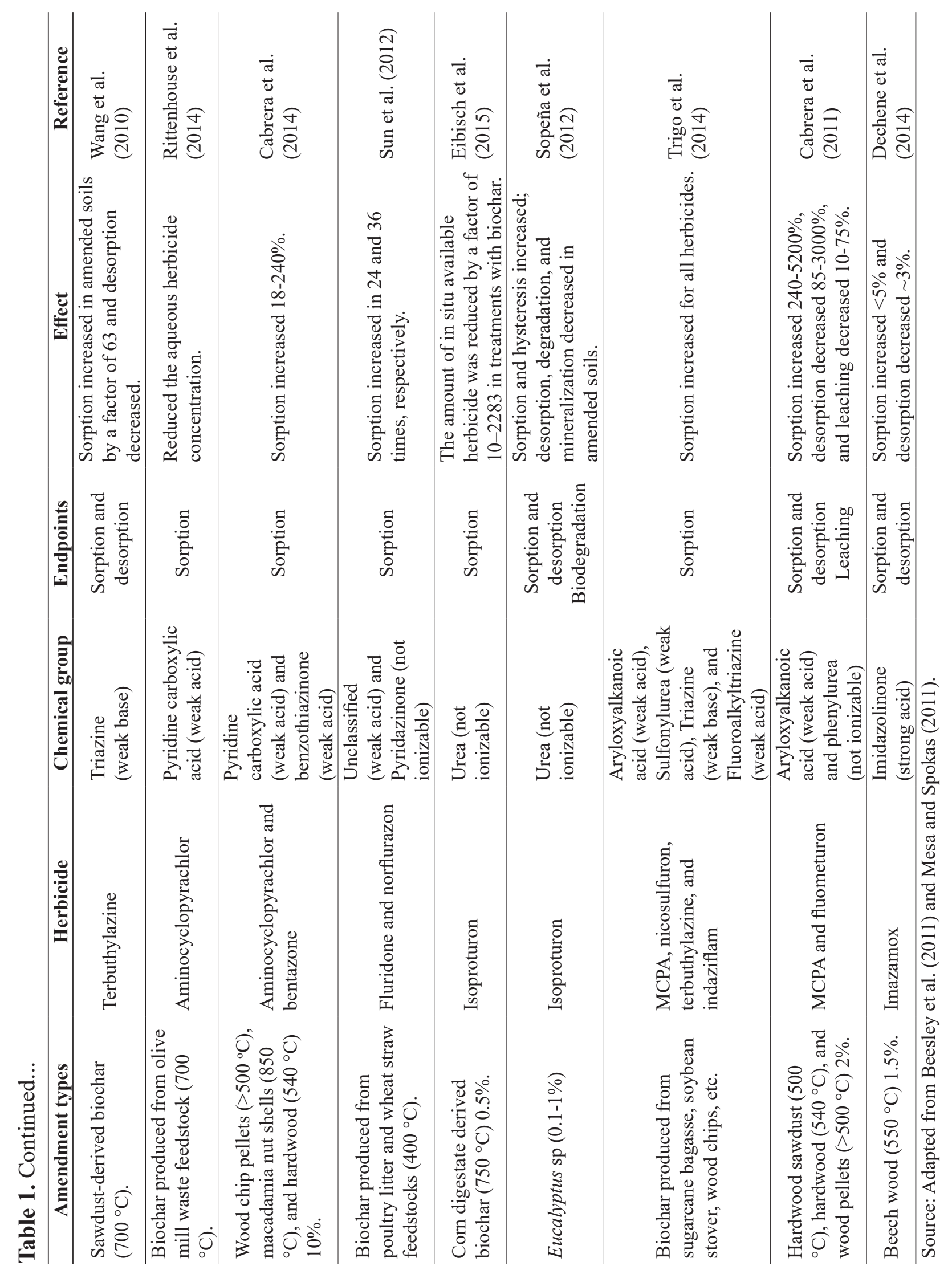


authors affirmed that biochar demonstrated a clear and prominent potential to remedy soils contaminated with pesticides, including herbicides, by increasing soil sorption capacity, decreasing desorption and mobility of pesticides in soil, decreasing bioavailability of pesticides in soil pore water, which is considered to be the fraction bioavailable for soil organisms. Also, by improving soil microbial activity by providing essential nutrients and soil physicochemical properties such as $\mathrm{pH}, \mathrm{CEC}$ and water holding capacity.

Nevertheless, it is noteworthy that although biochar amendment has been extensively studied as a potential technology for the remediation of herbicide-contaminated soil, many aspects still need to be further studied in detail because the available results are insufficient and sometimes contradictory. Future research topics to address current questions about the efficacy of biochar amendment for soil remediation contamined with herbicide are necessary (Khorram et al., 2016). As already reported in this review, biochar is seen as beneficial in alleviating climate change, improving crop productivity, remedying the polluted environment, and recycling agricultural waste (Tang et al., 2013). The benefits of biochar are multiple, interrelated and include direct and indirect effects on the environment. The biochar remediation effect will help remove the contaminants and make the soil cleaner and healthier which will ensure the normal growth of various crops. Because several biochar benefits are all linked together and form a virtuous circle once an aspect is triggered, biochar may potentially be an attractive alternative in modern society to solve environmental and food problems faced by the rapid increase in population.

These same authors affirmed that it is important to emphasize that we should not ignore the different points of view based on solid arguments. Variation of the results suggests that the current application of biochar to the soil is not a one-size fit-all paradigm, rather than the comprehensive consideration of the properties associated with each case in particular.

The several potential benefits described by Tang et al. (2013), incorporated into the fact that biochar produced from a variety of biomass can potentially be a environmentally beneficial tool for environmental remediation, stimulates increased research on biochar in the world and initiates in this area in Brazil (Novotny et al., 2015). The same authors affirmed that biochat is a technology of particular interest for Brazil, since its "inspiration" is from the historical Amazon Dark Earth, and also because Brazil is the world's largest charcoal producer, generating enormous residue quantities in form of fine charcoal and due to the availability of different residual biomasses.

\section{Herbicides behavior in biochar-amended brazilian soils}

The increase in sorption and decrease in desorption show that the application of biochar is an important alternative for the remediation in soil leaching of diuron, especially in sandy soils (Petter et al., 2016), interfering negatively the weed management. In view of the high cost of biochar production in Brazil, this material has not yet been applied to soil, mainly in field conditions.

Biochar addition to soil has been reported to reduce the microbial degradation of pesticides due to sorption of the active compound. Jablonowski et al. (2013) investigated whether the addition of hardwood biochar alters the mineralization of atrazine in two atrazine-adapted soils from Belgium and Brazil at different moisture regimens. These authors found that biochar addition resulted in an equally high or even in a significantly higher atrazine mineralization compared to the soils without biochar, and the extent of atrazine mineralization was more influenced by the specific soil than by the addition of biochar. It was concluded that biochar amendment up to $5 \%$ by weight does not negatively affect the mineralization of atrazine by an atrazine adapted soil microflora. 
It is important to note that biochar effects on some soil physical, mechanical and hydrological properties have not been given the emphasis these attributes deserve, especially at field scale. Data from well-designed and properly implemented long-term field experiments are needed to develop credible recommendations for use by land managers and policy makers (Mukherjee and Lal, 2014).

These same authors also reported that various soil-biochar combinations at field scale should be tested for at least two successive seasons to allow for sufficient field-ageing of biochar before a conclusion can be derived on crop yield. Life-cycle and cost-benefit analyses are required to establish threshold biochar application rates under specific soil-biochar-crop scenarios. Thus, full cost-benefit analyses are required with consideration of both environmental and agronomic factors for biochars derived from various sources to assess the economic value of biochar.

A model to represent the data of the sorption and desorption coefficients $\left(\mathrm{K}_{\mathrm{d}}\right)$ in biochar-amended and unamended soils is proposed by Clay and Malo (2012). Thus, Mendes et al. (2016) evaluated the effect of amending soils with soybean stover, sugarcane bagasse, and wood chips derived biochars or raw feedstocks on the sorption-desorption of metolachlor applied in different soils from three US states (Minnesota, silt loam; Illinois, silty clay loam; and Pennsylvania, silt loam) (Figure 3).
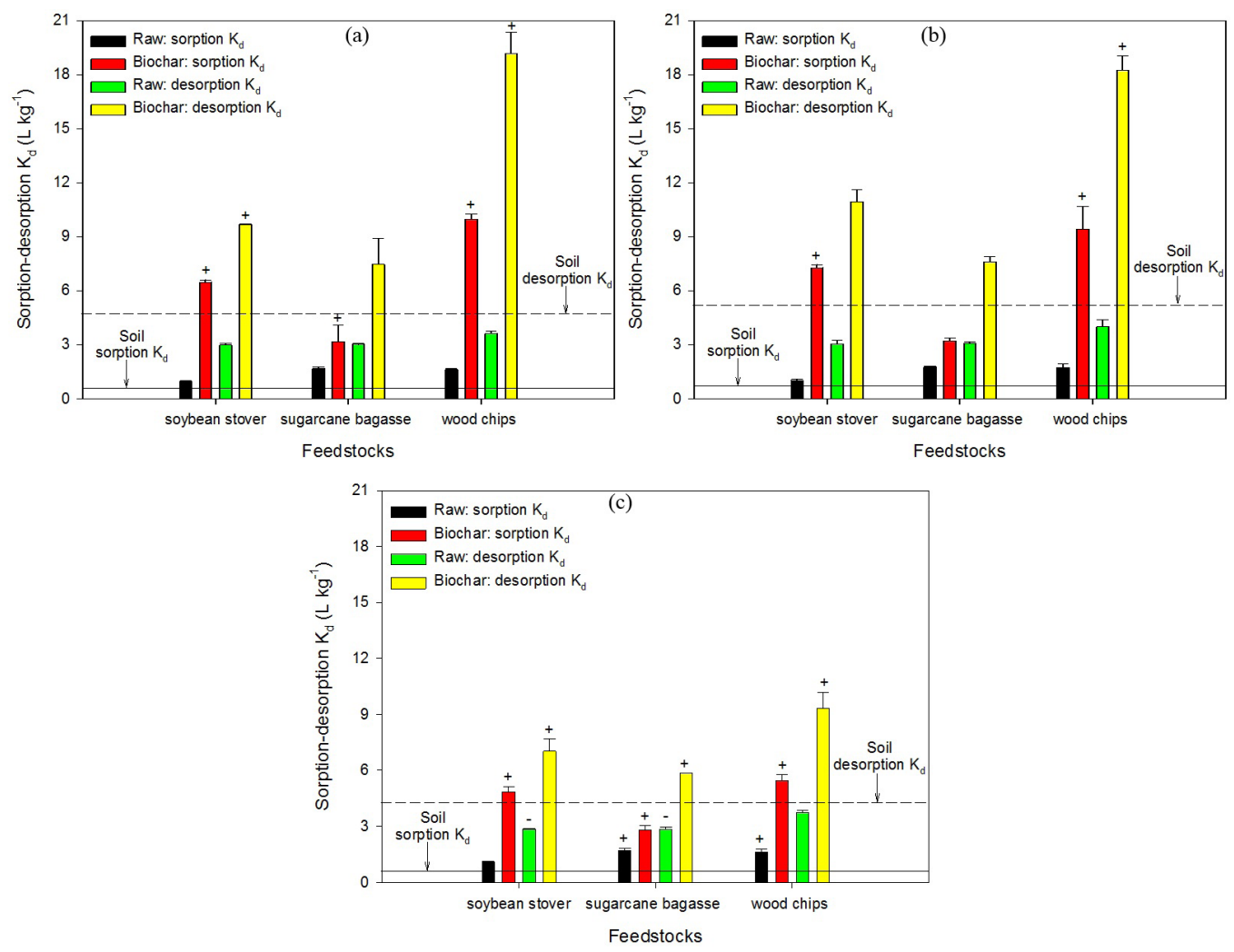

Figure 3. Sorption-desorption $\mathrm{K}_{\mathrm{d}}\left(\mathrm{L} \mathrm{kg}^{-1}\right)$ of metolachlor applied in soils from three US states [Minnesota, silt loam (a); Illinois, silty clay loam (b); and Pennsylvania, silt loam (c)] from the soil-only systems and with soybean stover, sugarcane bagasse, and wood chips derived biochars or same raw feedstocks. A “-" sign above the color bars indicates lower sorption-desorption $\mathrm{K}_{\mathrm{d}}$ and a "+" sign indicates great sorption-desorption $\mathrm{K}_{\mathrm{d}}$ than unamended soil (Dunnett's test at $p<0.05$ ). The vertical bars associated with each column represent the standard deviation $( \pm \mathrm{SD})$ of each mean value $(n=2)$. Source: Mendes et al. (2016). 
A batch sorption test was used to determine the concentration of ${ }^{14} \mathrm{C}$-metolachlor in a pseudosteady state with soil and biochar-soil systems at $10 \%(\mathrm{w} / \mathrm{w})$. Based on the sorption $\mathrm{K}_{\mathrm{d}}$ values, metolachlor was considered a relatively low sorption herbicide to the unamended three soils, with $\mathrm{K}_{\mathrm{d}}=0.55 \pm 0.04,0.61 \pm 0.08$, and $0.54 \pm 0.05 \mathrm{~L} \mathrm{~kg}^{-1}$ to $\mathrm{MN}, \mathrm{IL}$, and PA, respectively (Figure 3). Sorption of metolachlor increased up 18 times in all amended soils with biochar as compared to the unamended soil and desorption increased up 4 times. Biochar produced from wood chips feedstock was the most effective biochar that we assessed for reducing (73-83\%) the aqueous herbicide concentration. Therefore, the composition of the biochar in the amended soils can play an important role in the practical remediation by sorption-desorption of metolachlor, because these biochars reduced the herbicide concentration.

\section{Final considerations}

Overall, little is known about the behavior of herbicides in tropical soils amended with biochar. Then, more research is needed under our conditions to really understand the dynamics of this product in the soil.

The use of biochar in soils for agronomic purposes significantly reduces the bioavailability of the herbicides with a consequent direct effect in weed management, what may require increased doses to maintain the efficiency of the product when compared to the application in biochar-unamended soil. On the other hand, if small fields are contaminated with herbicides, the use of biochar as a bioremediation tool is potentially important because this technique is efficient to remove high amounts of the product.

Most biochar and herbicide behavior research were developed in laboratory and greenhouse, therefore the addition of biochar in the soil still requires more research under field conditions, since, in field, climate changes are important and influence the mineralization process, the soil physicochemical properties, and other factors such as soil erosion and heavy rain.

\section{Acknowledgements}

The São Paulo Research Foundation (FAPESP), process 2016/17683-1, for the financial support.

\section{References}

Beesley, L.; Jiménez, E.M.; Eyles, J.L.G.; Harris, E.; Robinson, B.; Sizmur, T. A review of biochars' potential role in the remediation, revegetation and restoration of contaminated soils. Environmental Pollution, v.159, n.12, p.3269-3282, 2011.

Bridgewater, A.V. Renewable fuels and chemicals by thermal processing of biomass. Chemical Engineering Journal, v.91, n.2-3, p.87-102, 2003.

Cabrera, A.; Cox, L.; Spokas, K.; Celis, R.; Hermosín, M.C.; Cornejo, J.; Koskinen, W.C. Comparative sorption and leaching study of the herbicides fluometuron and 4-chloro-2-methylphenoxyacetic acid (MCPA) in a soil amended with biochars and other sorbents. Journal of Agricultural and Food Chemistry, v.59, n.23, p.12550-12560, 2011.

Cabrera, A.; Cox, L.; Spokas, K.; Hermosín, M.C.; Cornejo, J.; Koskinen, W.C. Influence of biochar amendments on the sorption-desorption of aminocyclopyrachlor, bentazone and pyraclostrobin pesticides to an agricultural soil. The Science of the Total Environment, v.470/471, p.438-443, 2014.

Cao, X.; Ma, L.; Gao, B.; Harris, W. Dairy-manure derived biochar effectively sorbs lead and atrazine.

Environmental Science \& Technology, v.43, n.9, p.3285-3291, 2009.

Carvalho, M.T.M.; Madari, B.E.; Bastiaans, L.; van Oort, P.A.J.; Heinemann, A.B.; Silva, M.A.S.; et al. Biochar improves fertility of a clay soil in the Brazilian Savannah: short term effects and impact on rice yield. Journal of Agriculture and Rural Development in the Tropics and Subtropics, v.114, n.2, p.101-107, 2013. 
Clay, S.A.; Malo, D.D. The Influence of biochar production on herbicide sorption characteristics. In: Hasaneen, M.N. (Ed.). Herbicides - properties, synthesis and control of weeds. Rijeka, Croatia: In Tech, 2012. p.59-74.

Dechene, A.; Rosendahl, I.; Laabs, V.; Amelung, W. Sorption of polar herbicides and herbicide metabolites by biochar amended soil. Chemosphere, v.109, p.180-186, 2014.

Eibisch, N.; Schroll, R.; Fuss, R.; Mikutta, R.; Helfrich, M.; Flessa, H. Pyrochars and hydrochars differently alter the sorption of the herbicide isoproturon in an agricultural soil. Chemosphere, v.119, p.155-162, 2015.

Eykelbosh, A.J.; Johnson, M.S.; Couto, E.G. Biochar decreases dissolved organic carbon but not nitrate leaching in relation to vinasse application in a Brazilian sugarcane soil. Journal of Environmental Management, v.149, p.9-16, 2015.

Glaser, B.; Haumaier, L.; Guggenberger, G.; Zech, W. The 'Terra Preta' phenomenon: a model for sustainable agriculture in the humic tropics. The Science of Nature - Naturwissenschaften, v.88, n.1, p.37-41, 2001.

IBI - International Biochar Initiative. What is biochar? Available from: <http://www.biocharinternational.org/biochar>. Accessed: 09 jan. 2017.

Ippolito, J.A.; Laird, D.A.; Busscher, W.J. Environmental benefi ts of biochar. Journal of Environmental Quality, v.41, n.4, p.967-972, 2012.

Jablonowski, N.; Borchard, N.; Zajkoska, P.; Bayo, J.D.F.; Martinazzo, R.; Berns, A.E.; Burauel, P. Biochar-mediated [14C] atrazine mineralization in atrazine-adapted soils from Belgium and Brazil. Journal of Agricultural and Food Chemistry, v.61, n.3, p.512-516, 2013.

Khorram, M.S.; Zhang, Q.; Lin, D.; Zheng, Y.; Fang, H.; Yu, Y. Biochar: a review of its impact on pesticide behavior in soil environments and its potential applications. Journal of Environmental Sciences, v.44, p.269-279, 2016.

Lehmann, J.; Gaunt, J.; Rondon, M. Bio-char sequestration in terrestrial ecosystems - a review. Mitigation and Adaptation Strategies for Global Change, v.11, n.2, p.395-427, 2006.

Li, J.; Li, Y.; Wu, M.; Zhang, Z.; Lu, J. Effectiveness of low temperature biochar in controlling the release and leaching of herbicides in soil. Plant and Soil, v.370, n.1/2, p.333-344, 2013.

Maia, C.M.B.F.; Madari, B.E.; Novotny, E.H. Advances in biochar research in Brazil. Dynamic Soil. Dynamic Plant., v.5, n.1, p.53-58, 2011.

Mendes, K.F.; Hall, K.E.; Spokas, K.A.; Koskinen, W.C.; Tornisielo, V.L. Evaluating agricultural management effects on alachlor availability: tillage, green manure, and biochar. Agronomy, v.7, n.64, p.1-15, 2017.

Mendes, K.F.; Pimpinato, R.F.; Spokas, K.; Tornisielo, V.L. Assessing biochar's ability to reduce bioavailability of metolachor in three American soils. In: Simpósio Científico dos Pósgraduandos no CENA/USP, 9., 2016 Anais... Piracicaba: CENA/USP, 2016. p.39-40.

Mesa, A.C.; Spokas, K.A. Impacts of biochar (black carbon) additions on the sorption and efficacy of herbicides. In: Kortekamp, A. (Ed.). Herbicides and environment. Rijeka, Croatia: InTech, 2011. p.315-340.

Mukherjee, A.; Lal, R. The biochar dilemma. Soil Research (Collingwood, Vic.), v.52, p.217-230, 2014.

Nag, S.K.; Kookana, R.; Smith, L.; Krull, E.; Macdonald, L.M.; Gill, G. Poor efficacy of herbicides in biochar-amended soils as affected by their chemistry and mode of action. Chemosphere, v.84, p.1572-1577, 2011.

Novotny, E.H.; Maia, C.M.B.F.; Carvalho, M.T.M.; Madari, B.E. Biochar: pyrogenic carbon for agricultural use - a critical review. Revista 
Brasileira de Ciência do Solo, v.39, n.2, p.321344, 2015.

Petter, F.A.; Ferreira, T.S.; Sinhorin, P.A.; Lima, L.B.; Morais, L.A.; Pacheco, L.P. Sorção e dessorção de diuron em Latossolo sob a aplicação de biochar. Bragantia, v.75, n.4, p.487-496, 2016.

Petter, F.A.; Madari, B.E. Biochar: agronomic and environmental potential in Brazilian savannah soils. Revista Brasileira de Engenharia Agrícola e Ambiental, v.16, n.7, p.761-768, 2012.

Rehman, H.A.; Razzaq, R. Benefits of biochar on the agriculture and environment - a review. Journal of Environmental Analytical Chemistry, v.4, n.3, p.1-3, 2017.

Rittenhouse, J.L.; Rice, P.J.; Spokas, K.A.; Koskinen, W.C. Assessing biochar's ability to reduce bioavailability of aminocyclopyrachlor in soils. Environmental Pollution, v.189, p.9297, 2014.

Singh, B.; Singh, B.P.; Cowie, A.L. Characterisation and evaluation of biochars for their application as a soil amendment. Australian Journal of Soil Research, v.48, n.7, p.516-525, 2010.

Skjemstad, J.O.; Clarke, P.; Taylor, J.A.; Oades, J.M.; McClure, S.G. The chemistry and nature of protected carbon in soil. Australian Journal of Soil Research, n.2, v.34, n.1, p.251-271, 1996. Sopeña, F.; Semple, K.; Sohi, S.; Bending, G. Assessing the chemical and biological accessibility of the herbicide isoproturon in soil amended with biochar. Chemosphere, v.88, p.77-83, 2012.

Spokas, K.A.; Cantrell, K.B.; Novak, J.M.; Archer, D.A.; Ippolito, J.A.; Collins, H.P.; et al. Biochar: a synthesis of its agronomic impact beyond carbon sequestration. Journal of Environmental Quality, v.41, n.4, p.973-989, 2012.

Spokas, K.A.; Koskinen, W.C.; Barker, J.M.; Reicosky, D.C. Impacts of woodchip biochar additions on greenhouse gas production and sorption/ degradation of two herbicides in a Minnesota soil. Chemosphere, v.77, n.4, p.574-581, 2009.
Sun, K.; Gao, B.; Ro, K.S.; Novak, J.M.; Wang, Z.; Herbert, S.; Xing, B. Assessment of herbicide sorption by biochars and organic matter associated with soil and sediment. Environmental Pollution, v.163, p.167-173, 2012.

Tang, J.; Zhu, W.; Kookana, R.; Katayama, A. Characteristics of biochar and its application in remediation of contaminated soil. Journal of Bioscience and Bioengineering, v.116, n.6, p.653-659, 2013.

Trigo, C.; Spokas, K.A.; Cox, L.; Koskinen, W.C. Influence of soil biochar aging on sorption of the herbicides MCPA, nicosulfuron, terbuthylazine, indaziflam, and fluoroethyldiaminotriazine. Journal of Agricultural and Food Chemistry, v.62, n.45, p.10855-10860, 2014.

Wang, H.L.; Lin, K.; Hou, Z. Richardson, Gan, J. Sorption of the herbicide terbuthylazine in two New Zealand forest soils amended with biosolids and biochars. Journal of Soils and Sediments, v.10, n.2, p.283-289, 2010.

Yaman, S. Pyrolysis of biomass to produce fuels and chemical feedstocks. Energy Conversion and Management, v.45, n.5, p.651-671, 2004.

Yang, Y.N.; Sheng, G.Y. Enhanced pesticide sorption by soils containing particulate matter from crop residue burns. Environmental Science \& Technology, v.37, n.16, p.3635-3639, 2003.

Yang, Y.N.; Sheng, G.Y.; Huang, M.S. Bioavailability of diuron in soil containing wheat-straw-derived char. The Science of the Total Environment, v.354, n.2-3, p.170-178, 2006.

Yu, X.Y.; Ying, G.G.; Kookana, R.S. Sorption and desorption behaviors of diuron in soils amended with charcoal. Journal of Agricultural and Food Chemistry, v.54, n.22, p.8545-8550, 2006.

Zheng, W.; Guob, M.; Chowa, T.; Bennetta, D.N.; Rajagopalana, N. Sorption properties of greenwaste biochar for two triazine pesticides. Journal of Hazardous Materials, v.18, n.1-3, p.1121-1126, 2010. 